\title{
Environmental tritium in the vicinity of Creys-Malville nuclear power plant
}

\author{
E. Fourré ${ }^{1}$, D. Baumier ${ }^{1}$, A. Dapoigny ${ }^{1}$, P. Bonté ${ }^{1}$, B. Clavel $^{2}$ \\ and P. J ean-Baptiste ${ }^{1}$ \\ ${ }^{1}$ IPSL, Laboratoire des Sciences du Climat et de l'Environnement, UMR CEA-CNRS, Centre \\ d'Études de Saclay, 91191 Gif-sur-Yvette Cedex, France \\ ${ }^{2}$ EDF-CIDEN, 35-37 rue Louis Guérin, BP. 1212, 69611 Villeurbanne Cedex, France
}

\begin{abstract}
The results of an environmental survey of tritium in the vicinity of Creys-Malville nuclear plant are presented. The plant, which was shut down in 1998, is currently in its initial stage of dismantling. Measurements in the terrestrial environment do not provide any indication that tritium levels are significantly above the regional background. Tritium concentrations in groundwaters and in the river Rhône waters are at their background level too, with values in the range 0.94-1.64 Bq/l. In contrast, the various aquatic compartments of the river (fishes, plants, sediments) show enriched non-exchangeable bound tritium concentrations both upstream and downstream of the power plant, with values up to $14.7,49$ and $1495 \mathrm{~Bq} / \mathrm{kg}$ (dry weight) respectively. Although fine particles of tritiated compounds entering in the composition of luminous paints have been suspected on several occasions, the nature and the origin of this tritium source, which is not related to the nuclear plant, remain unknown and will require further investigations.
\end{abstract}

\section{INTRODUCTION}

Tritium (notation ${ }^{3} \mathrm{H}$ or $\mathrm{T}$ ) is a radioactive isotope of hydrogen. It is mainly present in nature in the form of tritiated water molecules. Hence, tritium is closely linked to the water cycle in the hydrosphere and the biosphere. HTO molecules are easily taken up by plant tissus through leaves and roots. Transfer to upper trophic levels occurs by water intake or water vapour inhalation and by the food chain. Tritium present in organic compounds is divided into two categories, Tissue Free-Water Tritium (TFWT) and Organically Bound Tritium (OBT). TFWT equilibrates very rapidly with the surrounding medium. The OBT is further classified as exchangeable and non-exchangeable ${ }^{3} \mathrm{H}$ : in organic molecules, the hydrogen atoms bound to atoms such as oxygen (hydroxyl group $\mathrm{OH}$ ), nitrogen or sulphur isotopically exchange with surrounding water and tend to equilibrate in a matter of hours with the local environment. In contrast, those bound to carbon atoms keep the isotopic signature acquired when the molecule was formed. Hence, the non-exchangeable hydrogen pool is representative of the environmental tritium level during the growing period of the organism and can be considered as the memory of past ${ }^{3} \mathrm{H}$ concentrations.

Tritium is naturally formed by the interaction of cosmic radiations with the upper atmosphere. The production rate is of the order of $0.25{ }^{3} \mathrm{H}$ atoms $/ \mathrm{cm}^{2} / \mathrm{sec}$ [1]. Natural tritium level are very low, not exceeding a few tenths of $\mathrm{Bq} / \mathrm{l}$ in precipitation and surface waters. This natural background has been largely affected by the radioactive fallouts of the atmospheric nuclear bomb tests of the 50's and early 60's, leading to an increase of tritium levels in precipitation by about three orders of magnitude. Since the atmospheric tests ban treaty was signed in 1963, tritium levels have decreased steadily owing to radioactive decay and dilution within the hydrosphere. Tritium is also present in the atmospheric and liquid effluents of the nuclear industry, including nuclear reactors, reprocessing plants and weapons production facilities, as well as in the luminous compounds industry. 
In this work, we report tritium concentrations in various environmental samples representative of the terrestrial and aquatic compartments of the environment in the vicinity of the Creys-Malville nuclear plant.

\section{SITE DESCRIPTION}

The Creys-Malville power plant, which is a 1200 MWe fast neutrons nuclear reactor, is located on the left bank of the River Rhône approximately $100 \mathrm{~km}$ dowstream of the Lake of Geneva and $45 \mathrm{~km}$ east of the city of Lyon. It was shut down in 1998 after 13 years of operation marked by a series of disruptions due to technical problems and fierced political opposition from environmental groups. It is currently in its initial stage of dismantling. The nuclear fuel has been unloaded. The next step will be the removal and on-site reprocessing of the 5500 metric tons of metal sodium used as a cooling fluid in the reactor.

Creys-Malville is a rural area. The main ecological compartments of the terrestrial environment consist of agricultural lands (cultivated lands, meadows used for cattle-breeding and vineyards on hill slopes) as well as woody areas. The aquatic environment is primarily that of the river Rhône. The hydrologic regime of the river, which is strongly influenced by the Alpin massif, is characterized by a minimum volume transport in winter and a maximum in summer, with a mean water flow at Sault-Brenaz (a few kms downstream of Creys-Malville) of the order of $450 \mathrm{~m}^{3} / \mathrm{sec}$. The section of the river between the Lake of Geneva and Creys-Malville is already strongly anthropised, with several hydroelectric dams and various installations aimed at regulating the river flow.

\section{SAMPLING AND ANALYSIS}

The samples were collected in september 2002 and 2003. The wind direction is mainly along an NW-SE axis, with prevailing winds from the northwest throughout the year. Hence, the area of Malville, located immediately downwind of the plant is under the direct influence of any potential atmospheric release. In constrast, the Ambléon sector located to the east beyond the Tentanet hill chain can be considered as a reference area (fig. 1). In the terrestrial environment, the sampling strategy focused on the soil/grass/milk chain. Samples from the aquatic environment were taken upstream and dowstream of the establishment. They consisted of groundwaters, river waters, sediments, aquatic plants and fishes.

The liquid samples were taken in $500 \mathrm{ml}$ Pyrex bottles previously baked at $120^{\circ} \mathrm{C}$ in a vacuum oven and filled with argon. Soils and sediments samples were placed in plastic boxes and stored in a freezer $\left(-20^{\circ} \mathrm{C}\right)$. Plant samples were also stored in plastic bags at $-20^{\circ} \mathrm{C}$. The fishes were captured with an electric device. For each sampling station, 500 grams of fillets (combined muscles and skin) were collected and stored in a freezer in plastic bags.

Tritium was measured using the helium-3 ingrowth method, a technique, which has been widely used in oceanography. The principle of the method is to remove the ${ }^{3} \mathrm{He}$ initially dissolved in the sample by degassing under high vacuum, then to store it in a closed container (usually a glass bulb) to allow the accumulation of tritiumgenic ${ }^{3} \mathrm{He}$. The tritium content of the sample is subsequently deduced from the mass spectrometric determination of the amount of ${ }^{3} \mathrm{He}$ produced during the storage time. Since helium diffusivity is very high in organic compounds, including biological tissus, allowing the tritiumgenic ${ }^{3} \mathrm{He}$ to diffuse out of the tissus and to accumulate in the storage container, there is no obstacle to apply this highly sensitive technique for measuring tritium in biological samples [2].

Liquids (water, milk) were analyzed using the procedure detailed by Jean-Baptiste et al. [3]. Soils and sediments were lyophilized and sieved $(<2 \mathrm{~mm})$. Other solid samples were equally dry-freezed and ground. For each sample, the tissue-free water collected in the lyophilisator was recovered for tritium analysis. 25-30 grams of dry material ( $0.1 \mathrm{~kg}$ to $1 \mathrm{~kg}$ for sediments and soils respectively) were further equilibrated with 4 liters of tritium free water to bring the exchangeable hydrogen pool tritium 
concentration to zero [4-5]. After an equilibration time of 48 hours, each sample was again lyophilized and stored under vacuum in a sealed glass vessel (Corning 1724) for ${ }^{3} \mathrm{He}$ ingrowth. All manipulations were done in a glove box filled with argon to avoid any contamination by ambient water vapour. Analytical precision is better than $5 \%$.
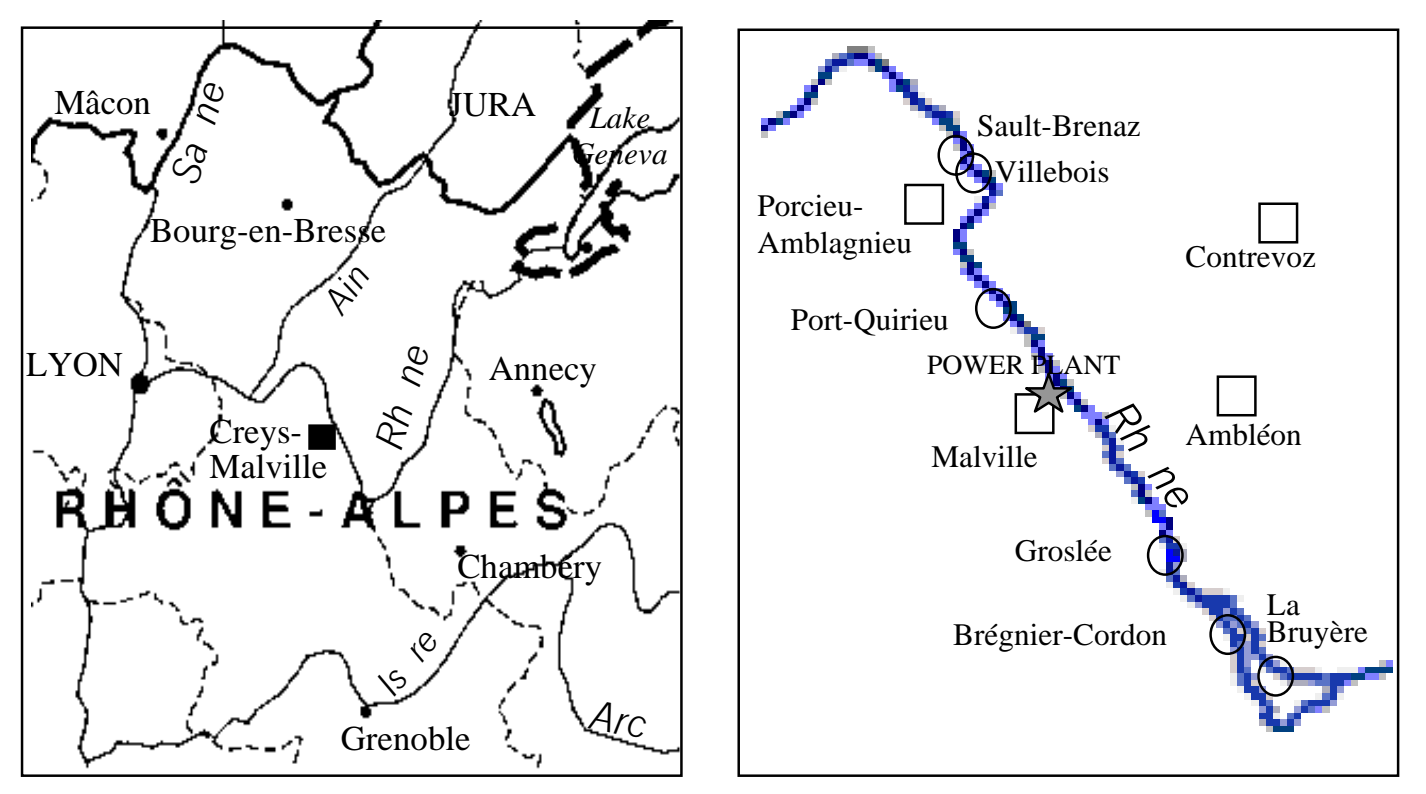

Figure 1. Creys-Malville nuclear power plant and sampling stations.

\section{RESULTS}

\subsection{Tritium concentrations in terrestrial samples}

The regional history of tritium concentrations in precipitation can be drawn (fig. 2a) from the time-series obtained in the cities of Thonon-les-Bains and Nyon located about $100 \mathrm{~km}$ away from the site, close to the lake of Geneva, and in the city of Bern situated $200 \mathrm{~km}$ to the northeast of the plant [6]. Available data in 1965 and 1966 at the station of Ambérieu-en-Bugey located next to Creys-Malville [6] are in good agreement with these data, indicating that these time-series are representative of the local tritium background in the vicinity of Creys-Malville.

The results of the present tritium survey in 2002 and 2003 are summarized in Table 1 and displayed in figure 2a. Non-exchangeable OBT concentrations in soils are between 0.45 and $0.70 \mathrm{~Bq} / \mathrm{kg}$ (dry weight). Using the measured hydrogen content (Table 1) and assuming an exchangeable hydrogen fraction of $20 \%$ [7], these values corresponds to a $\mathrm{T} / \mathrm{H}$ isotopic ratio in the range 85 - $150 \mathrm{TU}$ (1 TU corresponds to an isotopic ratio of $10^{-18}$ ). Non-exchangeable OBT levels in grass collected over the same soils are in the range 15.8 - $46 \mathrm{TU}(0.8-2.3 \mathrm{~Bq} / \mathrm{kg}$ of dry material) with no clear trend between Malville and the reference site of Ambléon. Non-exchangeable OBT concentrations in milk are also similar at both sites, between 17.5 and $18.3 \mathrm{TU}$, with a total tritium content in fresh milk (including Free Water Tritium and OBT) in the range 9.7 - 12.1 TU (1.1 - 1.4 Bq/l). 
Table 1. Tritium results for the terrestrial environment.

\begin{tabular}{|c|c|c|c|c|c|c|c|c|c|}
\hline \multirow{3}{*}{ Station } & $\begin{array}{c}\text { Sample } \\
\text { type }\end{array}$ & $\begin{array}{c}\text { Hydrogen } \\
\text { content } \\
\text { (\% dry weight) }\end{array}$ & \multicolumn{2}{c|}{$\begin{array}{c}\text { Free Water } \\
\text { Tritium } \\
(\mathrm{Bq} / \mathrm{l})\end{array}$} & $\begin{array}{c}\text { Non-exchangeable } \\
\text { Bound Tritium } \\
(\mathrm{Bq} / \mathrm{kg} \text { dry weight })\end{array}$ & \multicolumn{2}{c|}{$\begin{array}{c}\text { Non-exchangeable } \\
\text { Bound Tritium } \\
\text { TU (Tritium Unit) }\end{array}$} \\
\cline { 2 - 9 } Ambléon & 2002 & 2003 & 2002 & 2003 & 2002 & 2003 & 2002 & 2003 \\
& Soil & 0.69 & 0.50 & - & - & 0.50 & 0.47 & 85 & 110 \\
& Grass & 5.9 & 5.9 & 2.6 & 3.8 & 2.2 & 2.3 & 44 & 46 \\
& Salad & - & 5.6 & - & 2.1 & - & 0.95 & - & 20 \\
& Milk & 7.7 & 7.7 & 1.4 & 1.4 & - & 1.2 & - & 18.3 \\
\hline \multirow{5}{*}{ Malville } & Soil & 0.62 & 0.35 & - & - & 0.70 & 0.45 & 132 & 150 \\
& Grass & 6.0 & 6.0 & 2.3 & 4.3 & 2.3 & 0.80 & 45 & 15.8 \\
& Salad & - & 5.5 & - & 1.3 & - & 1.13 & - & 24 \\
& Milk & 7.7 & 7.7 & 1.1 & 1.37 & - & 1.15 & - & 17.5 \\
\hline
\end{tabular}

\subsection{Tritium concentrations in aquatic samples}

Our results are indicated in Table 2 and figure 2b. Tritium monitoring of the river Rhône waters by the Swiss federal public health agency [8-9] at Chancy, located at the French border, are in good agreement with precipitation data (fig. 2b), thus showing no tritium anomaly in the waters leaving the lake of Geneva. Tritium concentrations measured in the river Rhône both upstream and downstream of the Creys-Malville nuclear plant, in the range 1.56 - $1.59 \mathrm{~Bq} / \mathrm{l}$ (13.2 -13.5 TU), are fully consistent with these data, indicating no contamination of the river waters.
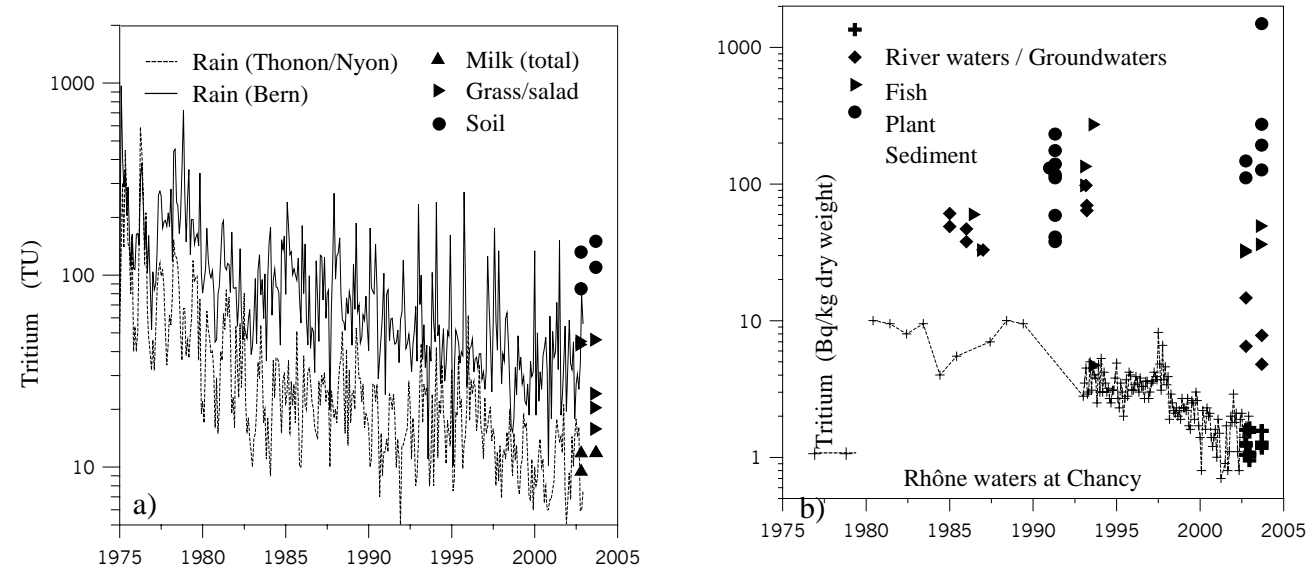

Figure 2. Tritium results for the terrestrial (a) and aquatic (b) environments in the vicinity of Creys-Malville. Aquatic data before 2000 are from IRSN [10, 14]. For solid samples, the data refer to the non-exchangeable OBT. For milk, the plotted results correspond to the total tritium activity (FWT+OBT).

Concentrations in groundwaters are between 0.94 and 1.64 Bq/l (8.0 - 13.9 TU), again showing no sign of contamination of the water table. In contrast, aquatic plants and fishes upstream and downstream of the reactor are significantly enriched in tritium (fig. 2b), with non-exchangeable OBT values in the range 32 - $49 \mathrm{~Bq} / \mathrm{kg}$ and $4.8-14.7 \mathrm{~Bq} / \mathrm{kg}$ (dry weight) respectively. Non-exchangeable OBT concentrations in sediments are even higher, both upstream and downstream, with values in the range 111 - $1495 \mathrm{~Bq} / \mathrm{kg}$ (dry weight). In figure 2b, the results are expressed in $\mathrm{Bq} / \mathrm{kg}$ instead of TU since there is no evidence so far that the elevated tritium levels can be assigned to the organic matter (see discussion below). 
Table 2. Tritium results for the aquatic environment.

\begin{tabular}{|c|c|c|c|c|c|c|}
\hline & \multirow[t]{2}{*}{ Station } & \multirow[t]{2}{*}{$\begin{array}{l}\text { Sample } \\
\text { type }\end{array}$} & \multicolumn{2}{|c|}{$\begin{array}{l}\text { Free Water } \\
\text { Tritium } \\
(\mathrm{Bq} / \mathrm{l}) \\
\end{array}$} & \multicolumn{2}{|c|}{$\begin{array}{l}\text { Non-exchangeable } \\
\text { Bound Tritium } \\
\text { (Bq/kg dry weight) }\end{array}$} \\
\hline & & & 2002 & 2003 & 2002 & 2003 \\
\hline \multirow{13}{*}{ 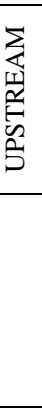 } & Contrevoz & Groundwater & 1.04 & - & & \\
\hline & Brégnier-Cordon & River water & - & 1.56 & & \\
\hline & La Bruyère & Sediment & - & - & 111 & 127 \\
\hline & La Bruyère & Myriophyllum spitacum & - & 1.60 & - & 36 \\
\hline & Brégnier-Cordon & Cinclidotus aquaticus & 1.94 & - & 32 & - \\
\hline & Groslée & Fish & - & 3.3 & 6.5 & 7.8 \\
\hline & Malville & Groundwater & 1.27 & - & & \\
\hline & Power plant & Piezometer N1 & 1.09 & - & & \\
\hline & Power plant & Piezometer N2 & 0.94 & - & & \\
\hline & Power plant & Piezometer N3 & 1.01 & - & & \\
\hline & Power plant & Piezometer N5 & 1.64 & 1.23 & & \\
\hline & Power plant & Piezometer N6 & 1.53 & 1.17 & & \\
\hline & Power plant & Piezometer N7 & 1.05 & - & & \\
\hline \multirow{8}{*}{ 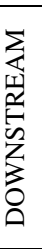 } & Porcieu-Amblagnieu & Groundwater & 1.22 & 1.29 & & \\
\hline & Port-Quirieu & River water & 1.59 & 1.56 & & \\
\hline & Port-Quirieu & Sediment & - & - & 148 & 274 \\
\hline & Villebois & Sediment 1 & - & - & - & 193 \\
\hline & Villebois & Sediment 2 & - & - & - & 1495 \\
\hline & Villebois & Myriophyllum spitacum & - & 1.60 & - & 49 \\
\hline & Sault-Brenaz & Cinclidotus aquaticus & 2.7 & - & 33 & - \\
\hline & Port-Quirieu & Fish & - & 4.8 & 14.7 & 4.8 \\
\hline
\end{tabular}

\section{DISCUSSION AND CONCLUDING REMARKS}

Tritium levels in the terrestrial environment in the immediate vicinity of the plant (Malville) and at the reference station (Ambléon) are comparable. This is consistent with the quite modest tritium atmospheric releases of the nuclear plant [10-11]. TWFT and non-exchangeable OBT concentrations in grass and milk are close to the regional tritium background level observed in precipitation. Based on radiocarbon studies [12-13], organic matter in temperate soils fall into three main pools of approximately equal size but with increasing residence time $\tau$ : a fast turnover pool (labile organic matter, $\tau=3-20 \mathrm{yr}$ ), a medium turnover pool ( $\tau=20-100 \mathrm{yr}$ ) and a slow turnover pool made of refractory matter ( $\tau>100 \mathrm{yr})$. Owing to this fact, the slightly above background tritium values in soils at Malville and Ambléon can be interpreted as the memory of higher background levels in the recent past decades.

Tritium concentrations in groundwaters and river waters are indistinguishable from the background (fig. 2b). This is in contrast with the non-exchangeable OBT values measured in various aquatic species, and specially in the river sediments whose bound tritium concentrations are significantly elevated. These high values are consistent with previous measurements [10, 14] made by the French Institute for radioprotection and nuclear safety (IRSN) between 1985 and 1993 (fig. 2b). The fact that this tritium enrichment is observed both upstream and downstream of the nuclear plant led the IRSN to postulate that the source of tritium could originate from the clock industry [15] in the form of fine particules of tritiated compounds used in luminous paints [15]. This would explain the preferential accumulation observed in sediments due to the settling of these particules in the river bed, and to a lesser extent on plants leaves and in the fishes which graze these plants. The large variability that we observe among the sediment samples (100 mg each) is another indication of the heterogeneity of this tritium source and is consistent with a statistical effect linked to a distribution of " hot " particles. However, enriched tritium concentrations can also result from the bioaccumulation of ${ }^{3} \mathrm{H}$ labelled organic compounds. Elevated OBT levels, up to $10^{5} \mathrm{~Bq} / \mathrm{kg}$ (dry weight), have been observed indeed in the benthic organisms and seafood of the Severn estuary [16] due to the presence of bioavailable ${ }^{3} \mathrm{H}$ labelled compounds in the wastes of the Nycomed-Amersham radiochemical plant (Cardiff).

In conclusion, we do not find any significant influence of the Creys-Malville nuclear reactor on the tritium distribution around the plant. Concerning the elevated tritium concentrations found in the Rhône biota and sediments, its origin is clearly independent of the power plant. The source and nature of this tritium signal cannot be identified on the basis of available data and will require further investigations. 


\section{References}

[1] Craig H., Lal D., Tellus 13 (1961) 85-105.

[2] Brown R.M, The measurement of tritium in Canadian Food Items (Report $n^{\circ}$ INFO-0499, Atomic Energy Control Board, Ottawa, Canada, 1995) pp. 32.

[3] Jean-Baptiste P. et al., Appl. Radiat. and Isotopes 43 (1991) 881-891.

[4] Hismatsu S. et al., Radioisotopes 39 (1990) 457-463.

[5] Ponturier F., Baglan N., Alanic G., Appl. Radiat. and Isotopes 61 (2004) 293-298.

[6] IAEA, Global Network of Isotopes in Precipitation / Isotope Hydrology Information System (GNIP/ISOHIS) at web site http://isohis.iaea.org/

[7] Belot Y., Radiat. Protection Dosimetry 16 (1986) 101-105.

[8] Murith C., Office Fédéral de la Santé Publique. Section de Surveillance de la Radioactivité, Fribourg, Suisse (Pers. Comm.), 2002.

[9] OFSP, Office Fédéral de la Santé Publique. Surveillance de la Radioactivité de l’Environnement (Suisse), Rapport annuel 2003.

[10] Beaugelin K., Thirion J.P., Bilan radioécologique décennal du CNPE de Creys-Malville - 1996, CEA/IPSN/DPRE, rapport SERE/97/029 (P), Cadarache, 1997.

[11] Roux C., EDF, CNPE de Creys-Malville (Pers. Comm.), 2004.

[12] Trumbore S., Global Biogeochemical Cycles 7 (1993) 275-290.

[13] Milton G.M. and Kramer S.J., Radiocarbon 40 (1998) 999-1011.

[14] Lumia G., Jourd'heuil L., Pally M., Etude radioécologique du site de Creys-Malville en 1993, CEA/IPSN/DPEI, rapport SERE/94/051 (P), Cadarache, 1994.

[15] Krejci K., Zeller A., Tritium pollution in the Swiss luminous compound industry, in: Behaviour of tritium in the environment, IAEA Proceedings Series, IAEA-SM-232/11, Vienna, 65-77, 1979.

[16] McCubbin D. et al., Marine Poll. Bull. 42 (2001) 852-863. 